\title{
The Jacobean Radical Picture of The White Devil
}

\author{
José Manuel González Fernández de Sevilla \\ Universidad de Alicante
}

\begin{abstract}
The White Devil presents a radical vision of Jacobean times. The play becomes a dramatic reflection of the crisis which brought about a new consciousness of life and death. Thus, it challenges an old order in need of change since everything is corrupted and abused. Characters are forced to live in a world of chaos and nonsense where ambiguity and appearances are the strategies to follow. Vittoria and Monticelso know how to use them to get power and social promotion. In this way drama shows a metatheatrical potential, for it contributes to give new solutions and to shape new expectations.
\end{abstract}

Things fall apart in The White Devil. Blackness and corruption get into the theatrical action from beginning to end and the dramatic illusion is transformed into a repetitive agonizing nightmare since "The ground base of the The White Devil is that Jacobean belief in the vanity of the world and of the impending collapse" (Farley-Hills 135). Thus Jacobean drama becomes "far more radical [than poetry]" because it contributes "to break the impasse; not indeed providing solutions, but suggesting new areas of enquiry..." (Wharton 3). Uncertainty and decay seem to be the only consistent reality that can explain the existential contradictions as the play, as T.S. Eliot points out, "will provide an interesting example of a very great literary and dramatic genius directed towards chaos" (117). And we find that the dramatic action is confronted and paralleled by dark historical events which meant England was not a peaceful and stable place to live in for there was "a definite break with the past," together with "a phase of unprecedented social and geographical mobility."

The dark Jacobean picture brought a new consciousness which is reflected in literature and religion where "Ministers filled their sermons...with vivid images of disorder, darkness, sickness and corruption." Undoubtedly "The times seemed out of joint."2 And 
once again drama shows itself to be a reflection of life. The White Devil is conclusive proof of the correlation between history and literature. You cannot fully come to terms with one without considering and taking into account the other. In this way we may say that it is not possible "to understand the history of seventeenth-century England without understanding its literature, any more than it is possible fully to appreciate the literature without understanding the history.." So what we get on stage is much more than we could expect. Life as such and social expectations are taken and transformed into dramatic fiction which, in its turn, shape and conform the audience's appreciation of contemporary events. We, therefore, should be aware of the close links between the social context and the theatrical action because there is a "recognizable image of the society outside and around the play." (Parry 2).

Webster takes the real dark side of reality as a crucial issue (Gunby et al. 19). The crisis the play dramatizes is not just a mere literary creation but a positive manifestation, through dramatic discourse, of the changes and fears which people had to face and suffer at that time. They provide a provocative material which yields a great variety of highly effective theatrical potential. Thus the play shows the preoccupations we find in Elizabethan and Jacobean drama which, time after time, present a dislocated and rotten social order on stage. Kyd, Marlowe and Shakespeare, among others, are also concerned with instability and corruption. John Webster continues this dramatic tradition and brings it to a conclusion. The White Devil, therefore, represents the furthest and last step of complete social chaos through personal corruption. There is no reasonable explanation for "the nightmare oppressiveness of the Websterian cosmos" (Wilks 194) which produces a "sense of defeat...of the futility of man's achievement" (Ellis-Fermor 152). Power, religion and social values are reversed and abused in the play, which becomes an undermining and provocative challenge to an old order which is in its final stages because of its inability to raise efficient and positive solutions to the emergence of new social expectations.

The corrupted state of the dramatic universe is clearly pointed out at the very opening of the play. It seems as if Webster, the "darkest of Jacobean tragic poets" (Bradbrook 1), had the intention of defining and presenting reality as a tragic defeat. And the introductory scene could not be more effectively done and dramatized, for Ludovico's "banish'd?"3 becomes a terribly disrupting and provoking statement. It questions the consistency and the possibility of such a social order based on corruption. Antonelli is very much astonished at hearing such a word. However, Ludovico does not pay attention to his reproach. To make matters more meaningful, his bloody actions and murders have been carried out in Rome and his banishment is from Rome as well. Thus the Holy City becomes a place of conflict. Vice and virtue share a common location since evil is everywhere. The characters cannot avoid living in this situation because it is the world to which they belong. Moreover, they consciously contribute to moral degradation since all values are on sale and all decisions and commitments could be reversed and exchanged in a minute. They are well aware of their wrongdoing.

Evil and devil are strongly interrelated in the play. The one presupposes the other. Monticelso becomes aware of their essential connection when he tells Vittoria, "...remove this evil, ...from thy breast that cruel devil" (4.3). The sin implies the sinner and the mischievous action, the wicked actor. The dramatic universe, therefore, becomes more and 
more infected and poisoned by human contributions for the whole political body is corrupted in its members:
I had a limb corrupted to an ulcer, But I have cut it off, and now I'll go
Weeping to heaven on crutches. For your gifts
I will return them all, and I do wish
That I could make you full executor
To all my sins.

The breaking of the moral order is a consequence of human will. In this way Brachiano becomes the "full executor" and Vittoria his "executrix" (5.6) who tries to involve Flamineo in her activity. But the production of evil has a gradation: if there are "degrees of evils", there are also "degrees of devils" (4.2) who change "this fair garden" into "all poisoned herbs" (1.2).

The visual artistry of Webster ${ }^{4}$ and the elaborated imagery ${ }^{5}$ he uses in the play reinforce the universal sense of chaos. Everywhere black is seen as the outstanding colour of the play, for everything is pictured and visualized in black as the expression of pervasive pessimism and nonsense. Corrupted words are combined with images of darkness. In this context, secret action and obscure images speak louder than words. The dark imagery employed is a manifestation of the internal infection through which the world becomes poisoned and rotten. The negative visualization is also stressed through animal symbolism. Henceforth the wolf and the raven (5.4) may well exemplify the appetites and attitudes the characters live for and suffer from in their daily fight for getting power, money and social promotion.

Ambiguity (Wymer 38) becomes the supreme rule to follow within the dramatic framework of the play. Webster is very careful in dramatizing the world as a mixture of good and bad where values "become problematic ..." (Leggatt 126) and characters are intentionally ambiguous. Their moral options will depend on the concrete situation and on the particular intentions. Thus Vittoria becomes the white devil for she is a "combination of beauty and corruption" (Leggatt 154). However the real dimension of ambiguity in the play can be seen in Flamineo, who is a most accomplished representative of the malcontent, one of the most peculiar characters to be seen on the Jacobean stage, that can be portrayed as

a man of impoverished background but good education, hoping to advance himself into favour at court and therefore in part a sycophant, yet taking upon himself many of the qualities of the all-licensed fool to castigate the follies and iniquities of the society he moves in. As his hopes of preferment dwindle, his cynicism deepens. (Cave 28).

$\mathrm{He}$ is even physically ambiguous. He acts in a very peculiar, sophisticated and uncompromising manner. He never asks but suggests. Moreover Flamineo cares for his master in the hope of getting a better social position, and he is not so generous as some of 
his actions might suggest. He is a frustrated intellectual who looks for social and economic promotion. Frustration and exploitation are the remarkable features of his alienated existence (Dollimore 242). He is chosen to provoke confusion within an irrational dramatic universe whithout any consistency and logic. ${ }^{6}$ Flamineo is dramatically used to fustigate a decadent society where appearances are the common strategy to deceive and manipulate "for some person or persons... are not what they seem, devils transformed into angels of light" (Brown 1). You cannot survive in this corrupted world without concealing your real aims and intentions. You can be a devil but you should behave as an angel. And in this craft Vittoria Corombona has no rival.

She is determined to be herself and to fulfil all her desires and female expectations. ${ }^{7}$ She is "above law, and above scandal" (1.2) though she has to appear the victim of mischief and sexual abuse. Vittoria becomes the prototype of the feminist heroine who strongly fights male prerogatives. She is the "assertive woman" who is strongly opposed to female oppression. Her personal challenge exemplifies "a significant change in attitudes to women in the drama of the second decade of the seventeenth century" (Dollimore 239). Vittoria's deceitful abilities and treacherous behaviour are no-where better shown than in the trial she has to stand for her possible involvement in the murder of Camillo, her husband. But she is well prepared to face all kinds of accusations. The linguistic manipulation initially carried out by the lawyer through his Latinate diction does not achieve the intended verbal confusion, for she confesses that she understands Latin. She tries to defend herself from intellectual provocation in order to appear intellectually equal to her detractors and accusers.

At this point words become an essential component for they can mean life or death for her. And this is why she prefers to have her trial delivered not in Latin but in the common language:

By your favour, I will not have my accusation clouded In a strange tongue: all this assembly Shall hear what you can charge me with.

Her plea makes sense since her culpability cannot be proved with facts, but it can be manipulated with words which, time after time, bring about confusion, becoming major agents of corruption. Besides Vittoria Corombona knows how to play with them because good and bad are just a question of verbal manipulation. And she becomes a manipulatrix of language in order to prove with all evidence her innocence for linguistic control means automatic success in the trial.

Monticelso knows it and he is ready to fight her linguistic arrogance whole-heartedly and to counter her verbal predominance. There is a linguistic confrontation through a repetitive manipulation of the concepts of justice and truth which begins with the proclamation of Vittoria's culpability. Monticelso, under these circumstances, tries hard to destroy her since both are partners in plotting evil with similar weapons. And his first strategy will be to reveal her real identity because she is not what she appears: 
What are whores!

They are those flattering bells have all one tune, at weddings, and at funerals. Your rich whores

Are only treasuries by extortion filled,

And emptied by cúrsed riot. They are worse,

Worse than dead bodies which are begged at gallows,

And wrought upon by surgeons, to teach man

Wherein he is imperfect. What's a whore!

She's like the guilty counterfeited coin,

Which whosoe'er first stamps it, brings in trouble

All that receive it.

It is a very serious charge against her. ${ }^{8}$ Whoredom is the expression and result of an infected world where accuser and accused share the same culpability and responsibility in the creation and production of evil. And the winner will be the one who will succeed in revealing the real motives and intentions of the enemy. It is precisely what Monticelso tries to do with Vittoria. He is decided to "paint out/ (her) follies in more natural red and white/ Than that upon (her) cheek" (3.2). He abuses his religious power in order to get rid of Vittoria at any cost for he is as prostituted as she is, and he cannot allow a partner to share his power and ambition. However she, in her turn, is determined to undermine male prerogatives using the same strategies. Her main argument is that the Cardinal is playing the role of the accuser rather than being a fair judge for he has not "an honest tongue" (3.3). And verbal rape is the main charge against the plotter of her destruction. Again appearances are of decisive importance to regain control because the characters must not reveal their real intentions and identity as in 5.3 when Francisco and Lodovico appear in the habit of Capuchins at Brachiano's deathbed. Appearances are also political in The White Devil and policy becomes the imitation of "The subtle foldings of a winter's snake,/ So who knows policy and her true aspect,/ Shall find her ways winding and indirect." (1.2).

Undoubtedly Monticelso is the most significant and cunning politician in the play. He devotes his life to power and authority. He reminds us of the Machiavellian prototype because he is essentially a manipulator who tries to use any means to get all ends. Religion is for him another form of control and abuse. The Cardinal personifies all powers, both human and divine for he is judge, minister and politician with dictatorial pretentions. He possesses the black book with "The names of all notorious offenders/ Lurking about the city.../The names of many devils"(4.1). And his election as Pope will be his greatest personal success as well as his best political achievement. Flamineo is he who tells us of the confusion we find in Rome because of the conclave.

The scene (4.3) opens with Francisco's words to Ludovico warning him of a possible manipulation. They must be on the watch in order to avoid "To bribe or to solicit the advancement/ Of any cardinal." But nothing can stop the election of Monticelso who is finally appointed Pope. And the excommunication of Vittoria Corombona will be the first public act carried out by Paulus IV: 
We cannot better please the Divine Power,

Than to sequester from the Holy Church

These cúrsed persons. Make it therefore known,

We do denounce excommunication

Against them both: all that are theirs in Rome

We likewise banish. Set on. (4.3)

Monticelso seems to speak ex cathedra. His dogmatic words clearly express his determination and intention. He is misusing his prerogatives and power. Papacy means for him the only possibility of settling the matter with Vittoria. Now he has all the chances to win for he represents justice and morality. There is no need of confrontation with her. His verdict will be the right one since excommunication is the worst ecclesiastical punishment which should correspond to the most evil deed of the most wicked kind. The faults by which Vittoria and Brachiano are condemned are not only a consequence of sexual abuse, immorality or murder. The sentence has a more radical justification according to Monticelso's appreciation. They are subject to excommunication not only for what they have done but also for what they are. Religion, therefore, becomes "the instrument of state power- a façade of sanctity..." (Dollimore 231). It is no longer the path for human salvation since money is the new god to be worshipped and glorified, "O gold, what a god art thou!" (3.3).

The material considerations the play contains from the beginning contrast with the concern about death (Andrews) which is intensely felt and visualized on stage through dark images. Webster's metaphysical style (Cave 37) contributes to emphasize its inevitability and necessity. ${ }^{9}$ Death seems to be the best and only possible escape from the "instability of such a world" (Morris 81). Besides there is a positive intention of creating an atmosphere of death as it can be seen in the ceremonies of the dumb shows. These dramatic rituals are performed to intensify the radical importance of death which is not only a sudden and private act but also has social implications. Death is considered to be $e^{10}$ an effective solution when there are obstacles for the accomplishment of personal promotion, sexual possession and radical revenge. Frustrated desires can be best fulfilled through death as it can be a consequence of a personal decision.

The most conscious reflection and recreation in the act of dying appears in the final scene of the final act where Flamineo stands as master of death. However the end of 5.4 marks the beginning of the consideration of its destructive power when he can't bear the presence of Brachiano's corporal deformity. Flamineo's words express the surprise of that strange meeting, "What a mockery hath death made of thee!" (5.4). And it is death that changes the ambiguity of his character. He knows that after his master's death life has no real meaning for he is no longer useful. He openly speaks of his new situation, "My life hath done service to other men,/My death shall serve mine own turn..." (5.6). Then his parasitical function (4.3) finishes. Now he must be himself. It is the time to face death as a remedy for his existential nonsense. Moreover Flamineo is ready to die "With as much pleasure,/ As e'er my father gat me" (5.6). He is determined to enjoy his last moments on earth. He wants to be conscious of such a decisive event and tries to perform his final tragic role as best as he can. And death becomes his greatest success because it has a 
purgative effect which allows characters to reveal themselves as they are. Death is the occasion and the time for self-revelation and authenticity as Flamineo's words show in his "farewell" to "daylight", to that "contemptible physic!" (5.6). He becomes a different man with deeper thoughts and resolutions. Thus he ceases "to die by dying" (5.6). At last he is aware of the nonsense of his alienated existence within a chaotic world from which he is longing to escape.

In this way The White Devil, with its tragic and negative picture, criticizes a vision of the world which cannot be sustained any longer for it is inhuman. And it is precisely here where the modernity of the play lies since it stands for "the dignity and integrity of human life, the need for freedom, and a heroic self-assertion in the face of chaos..." (Leggatt 153). It is a play of self-redemption and social regeneration through destruction. It manifests the need for the establishment of a more human world that could provide a solution to the present state of abuse and manipulation. The play, therefore, has a twofold implication, for its dramatized corruption implies metatheatrical restoration.

\section{Notes}

1. It was a general and substantial break since it meant a new undertanding of life and nature. Thus a new approach to reality was a relevant and revolutionary fact to bear in mind within the new Jacobean picture. It was then when "Scholasticism...was at length challenged by a new philosophy...In political the sixteenth-century conception of the monarch as the saviour of society and the theory of divine right of kings...were violently assailed, and substitutes of almost infinite variety were offered by theorists...In religion the Reformation had already rent in twain the seamless coat of the catholicism of the middle ages and had substituted a national for a universal church." G. Davies, The Early Stuarts 1603-1660, Oxford at the Clarendon Press, (1959), rpt. 1979, XXI-XXII.

2. As a result of this situation of conflict, which brought with it an acute conscience "of the more pathological symptoms of the process of change," English society was placed "under considerable strain." People, under these conditions, "tried to come to terms with changes which threatened their conception of a stable and enduring social order." K. Wrightson, English Society 1580-1600, London, Unwin Hyman, 1982, p. 149.

3. John Webster, "The White Devil", in Three Jacobean Tragedies, Gamini Salgado (ed.), Harmondsworth, Penguin (1965) rpt. 1969, 1.1. The quotations of the play are taken from this edition.

4. Webster's drama is essentially a visual and verbal theatre for it "is an unusual (although by no means unique) combination of two means of communication -words and pictures. The drama is created to be both spoken and produced, heard and seen." S. Schuman, The Theatre of Fine Devices: The Visual Drama of John Webster, Salzburg Institut für Englische, 1982, p. 5.

5. Imagery and morality are interrelated within the dramatic framework of the play. F.L. Goodwyn, Image Pattern and Moral Vision in John Webster, Salzburg, Institut für Englische, 1977.

6. This is a consequence of Webster's anti-rationalism. D. Goldberg, Between Worlds. A Study of the Plays of John Webster, Ontario, Canada, Wilfrid Laurier University Press, 1987, p. 12. 
7. There is debate about the extent of feminism in the play since Webster could "share [with Shakespeare] the prevalent misogyny." D. Gunby et al. (eds.), The Works of John Webster, vol. 1, Cambridge University Press, 1995, p. 26.

Moreover, the discontinuous presentation of Vittoria may be "connected with the uncertain subject position occupied by women in the early seventeenth century." Catherine Belsey, The Subject of Tragedy: Identity and Difference in Renaissance Drama, London, Methuen, 1985, pp. 160-164.

8. A. Loomba is right to maintain that "the unchaste woman is a moral rather than legal category, and since female morality is not a private matter, she is a public criminal." However Vittoria's most relevant and fundamental fault is not just moral but existential because she is a devil who produces evil through confusion and manipulation. Cfr. A. Loomba, Gender, Race, Reanissance Drama, Manchester University Press, 1989, p. 87.

9. Seventeenth Century Literature shares a positive concern with death. We find an "obsession with death" in "Metaphysical poets such as Donne and Quevedo." L. Elaine Hoover, John Donne and Francisco de Quevedo. Poets of Love and Death, Chapel Hill, The University of North Carolina Press, 1978, p. 204. It is a consequence not only of a literary fashion but also of a new consciousness of its inevitability and destructive power. See John Donne, "Satyre II", "Death Be not Proud”, Donne, J. Hayward (ed.), Harmondsworth, Penguin, (1950), rpt. 1986.

10 . We must say that the consciousness of death was a socially relevant fact for "the most striking feature which distinguished the Early Modern family from that of today does not concern either marriage or birth; it was the constant presence of death. Death was at the centre of life, as the cemetery was at the centre of the village." L. Stone, The Family, Sex and Marriage in England 1500-1800, Harmondsworth, Penguin, 1979, p. 54.

\section{Works Cited}

Andrews, Michael Cameron. This Action of Our Death. The Performance of Death in English Renaissance Drama. Newark: Delaware University Press, 1989.

Belsey, Catherine. The Subject of Tragedy: Identity and Difference in Renaissance Drama.

London: Methuen, 1985.

Bradbrook, M.C. John Webster. Citizen and Dramatist. London: Weidenfeld and Nicolson, 1980. Brown, J. Russell (ed.). The White Devil. The Revels Plays. Manchester: Manchester University Press, 1985.

Cave, R. Allen. The White Devil and the Duchess of Malfi. London: Macmillan, 1988.

Dollimore, Jonathan. Radical Tragedy: Religion, Ideology and Power in the Drama of Shakespeare and His Contemporaries.

Brighton: Harvester, 1984.

Eliot, T.S. Selected Essays. 1932. London: Faber, 1980.

Ellis-Fermor, Una. The Jacobean Drama: An Interpretation, London: Methuen, 1936.

Farley-Hills, David. Jacobean Drama. A Critical Survey of the Professional Drama 1600-1625.

Basingstoke: Macmillan, 1988.

Gamini, Salgado. Three Jacobean Tragedies. 1965. Harmondsworth: Penguin, 1969.

Goldberg, D. Between Worlds. A Study of the Plays of John Webster. Ontario, Can: Wilfrid Laurier University Press, 1987. 
Goodwyn, F.L. Image Pattern and Moral Vision in John Webster. Salzburg: Institut für Englische, 1977.

Gunby, D. et sl. (eds.), “General Critical Introduction.” The Works of John Webster. Cambridge: Cambridge University Press, 1995, vol. 1.

Hill, Christopher. “The Pre-Revolutionary Decades.” Collected Essays. 1985, I, 3.

Leggatt, Alexander. English Drama: Shakespeare to the Restoration. London: Longman, 1988. Jacobean Public Theatre, London: Routledge, 1992.

Loomba, A. Gender, Race, Renaissance Drama. Manchester: Manchester University Press, 1989.

Morse, D. England's Time of Crisis from Shakespeare to Milton. Basingstoke: Macmillan, 1989.

Morris, D. (ed.). John Webster. Mermaid Critical Commentaries. London: E. Benn, 1970.

Parry, G. The Seventeenth Century. London: Longman, 1989.

Schuman, S. The Theatre of Fine Devices: The Visual Drama of John Webster. Slazburg: Institut für Englische, 1982.

Wharton, T.F. Moral Experiment in Jacobean Drama. Basingstoke: Macmillan, 1988.

Wilks, John S. The Idea of Conscience in Renaissance Tragedy. London: Routledge, 1990.

Wymer, Rowland. Webster and Ford. Basingstoke: Macmillan, 1995. 